\title{
Access control using RFID cards and Raspberry Pi
}

\section{Control de acceso mediante tarjetas RFID y Raspberry Pi}

\author{
HERRERA-SERRANO, Jorge Eduardo†*, LOERA-RODRÍGUEZ, Jesús Isaí and LOPEZ-ALVAREZ, \\ Yadira Fabiola
}

Universidad Tecnológica del Norte de Aguascalientes, Estación Rincón, Rincón de Romos, Aguascalientes, 20400 México

ID $1^{\text {st }}$ Author: Jorge Eduardo, Herrera-Serrano / ORC ID: 0000-0002-3960-8406, CVU CONACYT ID: 881987

ID $1^{\text {st }}$ Coauthor: Jesús Isaí, Loera-Rodríguez / ORC ID: 0000-0002-3613-4356

ID $2^{\text {nd }}$ Coauthor: Yadira Fabiola, López-Álvarez / ORC ID: 0000-0002-9041-1908, Researcher ID Thomson: T-15552018, CVU CONACYT ID: 375952

DOI: 10.35429/EJDRC.2020.10.6.1.5

Received March 26, 2020; Accepted June 23, 2020

\begin{abstract}
This project seeks to strengthen the Information Center of the Universidad Tecnológica del Norte de Aguascalientes through an access control system for all those who use the facilities. These types of systems usually rely on biometric sensors such as fingerprints or face identifiers, however, RFID cards will be used for our case, because the University already has them. Embedded computation was used for the development of the prototype based on the development board known as Raspberry Pi and also the sensors to read card information. This project allows a better control within the Information Center and generates data that will be transformed into useful information for various areas of the University. While the main objective is to keep a check, the system will allow in the future to generate certain types of reports that will be very useful in the different certifications.
\end{abstract}

\section{Access control, RFID technology, Embedded computing}

\begin{abstract}
Resumen
Este proyecto busca fortalecer al Centro de Información de la Universidad Tecnológica del Norte de Aguascalientes mediante un sistema de control de acceso para todas aquellas personas que utilizan las instalaciones. Este tipo de sistemas por lo regular se apoya en sensores biométricos como huellas dactilares $\mathrm{o}$ identificador de rostro, sin embargo, para nuestro caso se utilizarán tarjetas RFID, debido a que la Universidad ya cuenta con ellas. Para el desarrollo del prototipo se utilizó cómputo embebido tomando como base la placa de desarrollo conocida como Raspberry Pi, además de los sensores para leer la información de las tarjetas. Con este proyecto se espera llevar un mejor control dentro del Centro de Información y generar datos que posteriormente se transformen en información útil para las diversas áreas de la Universidad. Si bien el objetivo principal es llevar un control, el sistema permitirá en un futuro generar cierto tipo de reportes que serán de gran utilidad en las diferentes certificaciones.
\end{abstract}

Control de acceso, Tecnología RFID, Cómputo embebido

Citation: HERRERA-SERRANO, Jorge Eduardo, LOERA-RODRÍGUEZ, Jesús Isaí and LOPEZ-ALVAREZ, Yadira Fabiola. Access control using RFID cards and Raspberry Pi. ECORFAN Journal-Democratic Republic of Congo. 2020, 610: $1-5$

$\dagger$ Researcher contributing first author. 


\section{Introduction}

An access control system can be seen as an identification system, which has had a huge impact in recent years in almost any field. These systems usually rely on biometric sensors to complement the registration, the most common being the fingerprint, although there is also the face detector. According to the author Alvarado, RFID technology can be seen as a wireless self-identification system, which consists of devices that can store information (Alvarado Sánchez, 2008). RFID technology is being adopted more and more by more industries due to its relatively lower cost than biometric sensors. These types of systems have been expanded to such a degree that they not only serve for access controls, they have also been implemented in transport systems, security, inventories, etc. This is due to its notable advantages in terms of productivity, administration and cost.

This project was born from the need to have accurate information about the people who use the Information Center, in addition to the fact that it is automated. The importance of this information lies in its use in audits in the study plans (PE) of the University, since the making of certain decisions depends on this. This project was planned to work in modules, so more functionalities will be added to it. In this first stage, only access control will work.

As mentioned above, it was decided to use RFID technology, because all students, teachers and administrations have an identification with this technology, due to the fact that there is a main access system. One of the main requirements of the project was to avoid islands of information, that is, not to generate a decoupled system from the one that originally exists at the entrance. This was a great challenge, because it was necessary to know in depth how the main system worked and especially the data storage. To solve this problem, a specific algorithm had to be developed to couple both systems.

\section{Implementation}

For the development and implementation of this project, a development methodology known as RAD (Rapid Application Development) was used, which will be discussed in its respective section.
Each of the functional requirements of the project was identified, since, from the point of view of any system, identifying the requirements is vital, since once the development begins there is no going back (Chaves, 2005). The first important requirement is that the identification cards have to be used and the second use the same database as the main access system to avoid redundant information. However, it is important to note that this system was a product of a third party and has been in operation for some time. In this system we already have all the data of both students and teachers, hence the importance of making them work as one.

RFID cards store information known as an identifier or TAG and this serves to differentiate one from another. For the implementation of the system, it was decided to use embedded computing. It is currently widely used in specific-purpose systems, in addition to having a particular characteristic that makes it the appropriate candidate, that is, reliability, which is essential in any system and is part of the pillars of software engineering. (Vega, 2010).

Although at first it was thought of using Arduino to make use of embedded computing, it was declined and it was decided to use Raspberry $\mathrm{Pi}$ boards, this due to the same project requirements and that there is more experience on this development board.

Figure 1 shows the first prototype, for this a basic access control architecture would be followed as a basis.

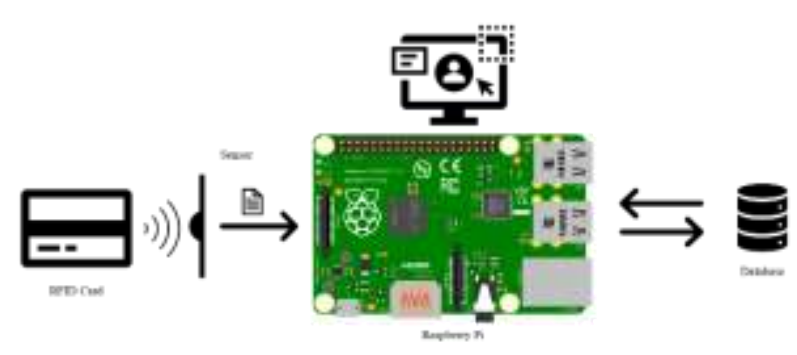

Figure 1 Access control system architecture Source: Self Made

The sensor used is an RDM6300 since it allows the reading of $125 \mathrm{KHz}$ RFID cards and the Python programming language was used for the development of the application. All the processing falls on the plate. 
In the encoding, it was necessary to make adjustments regarding the readings of the cards, an algorithm was carried out to synchronize the information stored by the reader and that saved. This algorithm was based on the conversion of numbering systems.

\section{Methodology}

Two proposals were analyzed. First, the cascading approach that requires each stage to be completed before starting a new one. This methodology requires extensive development time as well as very little interaction with the end user during the software coding stage. Because of this, he was rejected for this particular project. The second methodology considered is an agile approach. This approach requires extensive and intense interaction with end users and generally requires less time for overall project development.

Therefore, this is the best methodology for the type of project developed. Agile methods are universally based on an incremental approach to software specification, development, and delivery. They are best suited for application development where overall system requirements change rapidly during the development process. Sommerville's book (Sommerville, 2016) expresses a philosophy according to this type of methodologies; "We are discovering better ways to develop software by doing it and helping others to do it. Through this work we have come to value:

1. Individuals and interactions on processes and tools

2. Working software on complete documentation

3. Collaboration with the client on contract negotiation

4. Responding to change over following a plan

Due to the requirements and characteristics of the application required for this project, it was decided to use the agile methodology known as RAD (Rapid Application Development). This methodology was enunciated for the first time in the document of J. Martin (Martin, 1991). RAD processes are designed to produce useful software quickly.
The software is not developed as a single unit, but as a series of increments, and each increment includes new system functionality. In Figure 2, you can see the process followed for the development of applications based on this methodology.

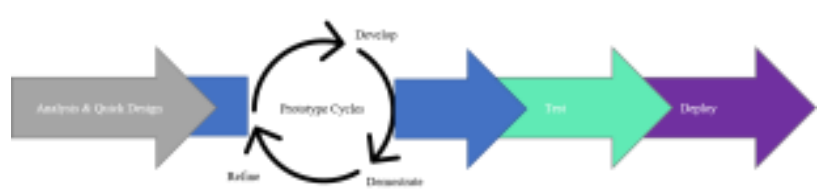

Figure 2 Basic access control

Source Based on the original by J.Martin (Martin, 1991)

During development and following the aforementioned methodology, some prototypes were generated that were changing and improving until the final prototype version was reached, which was already stable and met the previously defined requirements. The results of these tests can be displayed in the last results section.

\section{Results}

For the assembly of the prototype, the Raspberry Pi board was used, where the program is executed and in turn communicates with the sensor to obtain the labels of the cards. As a reader, an RDM6300 sensor was used, since the cards work at a frequency of $125 \mathrm{Khz}$. Components are displayed in Figure 3.

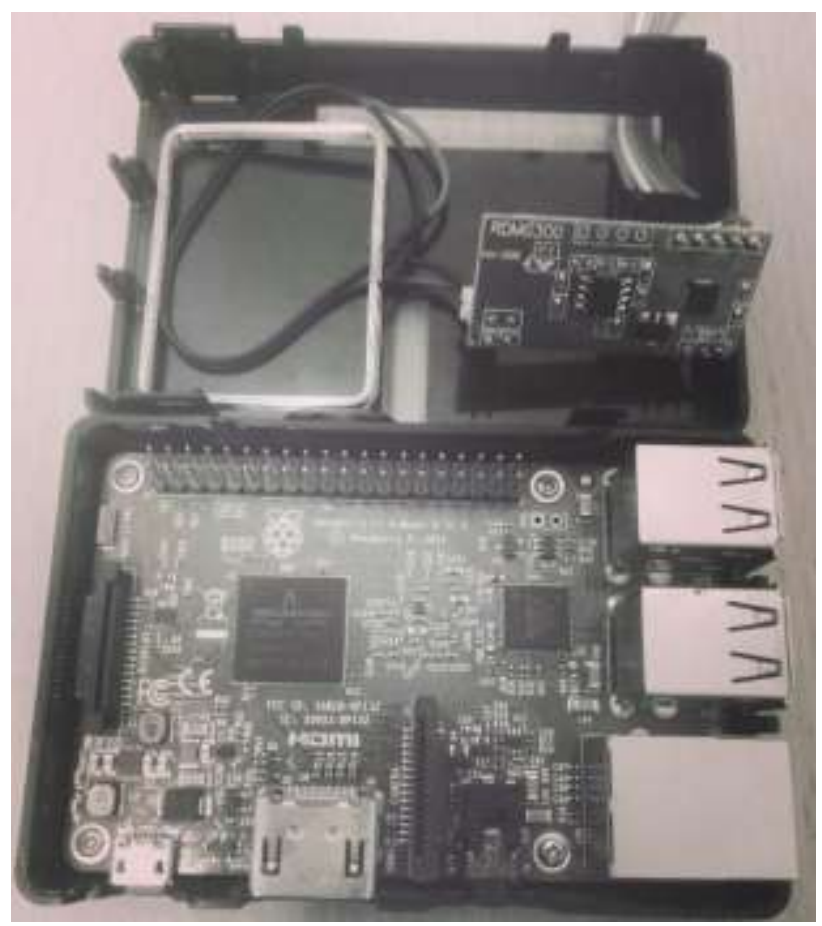

Figure 3 Raspberry Pi and RDM6300 sensor Source: Self Made

HERRERA-SERRANO, Jorge Eduardo, LOERA-RODRÍGUEZ, Jesús Isaí and LOPEZ-ALVAREZ, Yadira Fabiola. Access control using RFID cards and Raspberry Pi. ECORFAN Journal-Democratic Republic of Congo. 2020 
Then the system coding part was continued, where it was necessary to use Python due to its advantages in terms of the use of sensors (Torres et al., 2011)

The code was simple to implement, since the reader returns the tag of the cards, however, the difficult thing was to link this system with the previous one, since the information given by the reader did not coincide with that stored in the databases data from students and teachers, that is why it was necessary to implement the algorithm described above to perform tag conversions.

This algorithm was implemented in a function within the same code, for this it was necessary to implement number systems, specifically the hexadecimal to carry out conversions and thus make both labels coincide. A snippet of the code can be seen in Figure 4.

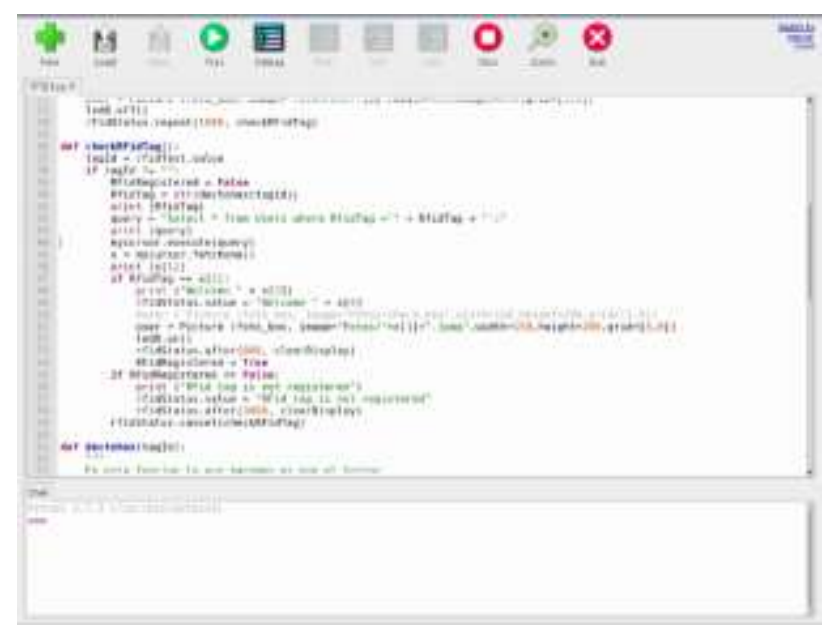

Figure 4 Source code snippet Source: Self Made

A light graphical interface was implemented, which guides both the user and the administrator (Acosta \& Zambrano, 2006). However, since the interface should not consume many resources and that access controls are of recurrent use, it was decided to show the basic and necessary elements to the user. The interface is shown in Figure 5.

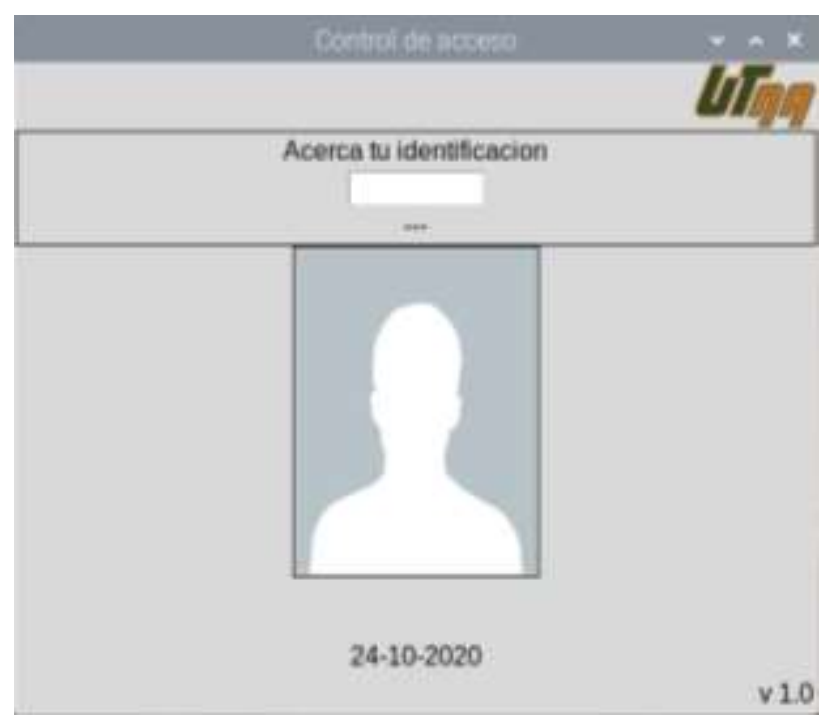

Figure 5 Main graphical interface Source: Self Made

By joining all the elements, there is then a complete system, which is expected to implement and carry out further tests, since it is necessary to measure efficiency and speed, in addition to the user experience.

\section{Conclusions}

This project is used to control access using RFID cards. The use of new technologies such as embedded and ubiquitous computing makes it possible to implement these types of projects with greater ease and lower cost, which were almost impossible to afford a few years ago (Durango et al., 2012). This prototype has the most basic functions, however, it is possible to add more functionalities and thus be a more complete system. Some of the tasks that you will be able to carry out in the future are already being considered, in addition to the fact that you also want to study the efficiency and benefits that it can bring compared to a conventional system.

It is also important to note that it is not the only way to implement the project, since as is known, this type of technology is on the rise and more and more are implemented, such is the case of the Arduino. As future work, it is intended to test the operation of this project using Arduino and make a comparison between the two (Casco, 2014). 


\section{References}

Acosta, A., \& Zambrano, N. (2006). Importancia, problemas y soluciones en el diseño de la interfaz de Usuario. SABER. Revista Multidisciplinaria del Consejo de Investigación de la Universidad de Oriente, 18(2), 174-182.

Alvarado Sánchez, J. A. (2008). Sistema de Control de Acceso con RFID. Trabajo Especial de Grado, Centro de Investigación y Estudios Avanzados del Instituto Politécnico Nacional. Escuela de Ingeniería Eléctrica. México, México.

Casco, S. (2014). Raspberry Pi, Arduino y Beaglebone Black Comparación y Aplicaciones. vol, 1, 4-8.

Chaves, M. A. (2005). La ingeniería de requerimientos y su importancia en el desarrollo de proyectos de software. InterSedes: Revista de las Sedes Regionales, 6(10), 1-13.

Durango, M. B., Ospina, N. L., Carvajal, J., \& Fonseca, A. (2012). Análisis y diseño de un prototipo de sistema domótico de bajo costo. Revista Facultad de Ingeniería Universidad de Antioquia(63), 117-128.

Martin, J. (1991). Rapid application development. Macmillan Publishing Co., Inc.

Sommerville, I. (2016). Desarrollo ágil de Software. Ingeniería de Software (págs. 72-74). Pearson.

Torres, B., Pang, Q., Skelton, G., Bridges, S., \& Meghanathan, N. (2011). Integration of an RFID reader to a wireless sensor network and using it to identify an individual carrying RFID tags. arXiv preprint arXiv:1105.0066.

Vega, J. I. H. (2010). El software embebido y los retos que implica su desarrollo. Conciencia Tecnológica(40), 42. 